Care Act of 1988"' (Ph.D., The Johns Hopkins University, 1990).

Robin Kolodny, "The Role of the Congressional Campaign Committee in Party Develop" ment and Leadership Selection in Congress" (Ph.D., The Johns Hopkins University, in progress).

\section{References \\ Bonafede, Dom. 1983. Interviewing Presiden- tial Aides: A Journalist's Perspective. In George C. Edwards III and Stephen J. Wayne, eds., Studying the Presidency. Knoxville: University of Tennessee Press. Dexter, Lewis A. 1970. Elite and Specialized}

Interviewing. Evanston: Northwestern University Press.

Fenno, Richard F., Jr. 1978. Home Style: House Members in their Districts. Boston: Little, Brown.

Fenno, Richard F., Jr. 1986. Observation, Context and Sequence in the Study of Politics. American Political Science Review 80: 3-15.

Gorden, Raymond L. 1980. Interviewing: Stratgegy, Technique, and Tactics. Homewood, IL: Dorsey Press.

Hammer, Dean and Aaron Wildavsky. 1989 The Open-Ended, Semi-Structured Interview: An (Almost) Operational Guide. In Aaron Wildavsky Craftways: On the
Organization of Scholarly Work. New Brunswick: Transaction Publishers.

Huitt, Ralph K. and Robert L. Peabody. 1969. Congress: Two Decades of Analysis. New York: Harper and Row.

Kuhn, Thomas. 1962. The Structure of Scientific Revolutions. Chicago: Chicago University Press.

Merton, Robert K. 1956. The Focused Interview: A Manual of Problems and Procedures. New York: The Free Press.

Pica, Joseph A. 1983. Interviewing Presidential Aides: A Political Scientist's Perspective. In George C. Edwards, III and Stephen J. Wayne, eds. Studying the Presidency. Knoxville: University of Tennessee Press.

\title{
The National Endowment for the Humanities and Political Science After 25 Years
}

\author{
Ellis Sandoz, Louisiana State University
}

When it started out in 1965 , the National Endowment for the Humanities (NEH) was viewed with high expectations by the political science fraternity in the United States. Those expectations have been amply fulfilled over the past quarter of a century. NEH has become today an important source of external funding for political scientists with a wide range of interests and for political science-related programs, teaching and research. Over $\$ 14$ million were devoted to such projects during the 1980s when a crescendo came with the Bicentennial of the Constitution.

\section{What were the initial expectations?}

In calling for establishment of NEH in 1964, the APSA mustered five distinguished members to draft a position paper: Herbert Deane of Columbia, John H. Hallowell of Duke, H. Malcolm Macdonald of Texas, Frederick M. Watkins of Yale, and Sheldon Wolin of California-Berkeley_political theorists all. What they saw as the chief desideratum in the wake of Sputnik, the gearing up for the space race in all fields of science and technology, and the surge of sciency behavioralism in political science is not surprising. As they wrote in controlled understatement:

Some areas of study in political science and some methods of pursuing that study are more generously endowed than others. It is in the interest of balanced support that we urge the establishment of a National Humanities Foundation. It is now somewhat easier for political scientists who are concerned with the use of quantitative methods to secure financial support for their research activities than it is for those among us whose interest in politics is more philosophically and normatively oriented. This is not to disparage the work of those who are endeavoring to make the study of politics more scientific; rather, it is a plea for the support of those areas of political research and training which are most directly related to the concerns shared by the humanities (Report of the Commission on Humanities, 201).

The urgent needs of political scientists that might be met by establishing NEH were identified as including: fellowships for able graduate students preparing to teach political science, with stress on support for travel to do research and attention to foreign language training; post-doctoral support; improving the teaching of government in secondary schools as a matter of citizenship training; programs to prepare textbooks and related instructional materials, especially as these bear on the nature and rise of communism because many states were mandating instruction in that subject; and money for research, giving priority to the field of political philosophy, since such roots of our own tradition as the "rule of law" as well as the bewildering array of "contemporary political ideologies" fall within the purview of theory.

"Research in political philosophy is the least well-endowed field of research in political science, but the questions to which it seeks answers are of ultimate concern," our authors argued (Report of the Commission on Humanities, 205). But such other areas as the study of public law, comparative government, public administration, and international relations were identified as intimately connected with the concerns of the humanities as well.

"The criterion for support of such projects by [the NEH] might be whether the research project was normatively oriented," the APSA spokesmen suggested. In the heydey of the aspiration to value-free 
science, this criterion then was defended with the argument that everything a government does has normative implications. The main consideration in the establishment of the Endowment is to assure "that no one normative judgment . . . be controlling and that freedom to investigate problems from competing normative perspectives ... be encouraged" through heavy reliance on juries of outside scholars, rather than on governmental officials, to pass on project proposals. So as to guarantee against bias and partisan political pressures, it was urged that "ultimate responsibility" for the functioning of the Endowment might be placed in an independent body of scholars (Report of the Commission on the Humanities, 206). This serene confidence in the fairmindedness of the academy here displayed is itself noteworthy.

\section{How have things turned out in comparison with early expectations?}

The vision of the authors of APSA's 1964 statement is close to the reality of the Endowment as it has developed since then and as it operates today. In fact, the range of programs fostering humanities' interests at all levels of education and serving instructional as well as research interests covers and far exceeds all of the specific areas of concern mentioned in the 1964 document. In addition, elaborate peer review procedures composed of panels and outside consultants screen proposals in every division of the Endowment in tiered sequences dedicated to fair treatment that lead, finally, to staff recommendations and to deliberations based on these by the specialized divisional oversight committees of the National Council on the Humanities. The entire Council in plenary session, then, makes final recommendations to the chairman on how virtually every nickel of the authorized budget of (now) $\$ 150+$ million ought to be expended each year.

Scholars are in nearly complete command of this process, since any departures from Council recommendations and the chairman's interim emergency grants must be accounted for to the Council at the following quarterly meeting. In any event, such exceptional discretionary actions are very few in number. Nor are the "officials" who comprise the staff of the Endowment nonscholars. This remarkable bureaucracy-at the senior levels all Ph.D.'s with substantial scholarly accomplishments to their credit-is composed of highly qualified professionals who could staff a liberal arts college faculty. The Council itself (composed of 26 presidential appointees in three cohorts, each member subject to Senate confirmation for a six-year term) is heavily drawn from academe so that roughly two-thirds of the present Council members are fulltime academics with professorial rank. It may or may not inspire further confidence among rank and file APSA members that three of these are deans and two are university presidents. ${ }^{1}$

The weakening of the putative behavioral orthodoxy in the intervening years in political science along with the sharp decline of respect for positivism has been accompanied, paradoxically, by an increased reliance on statistical methods of analysis in certain branches of the study of history and literature. Thus, the question of the precise criterion to be used in qualifying a political science proposal as a "humanities" project may be even murkier now than it was earlier. Even so, one hears little talk of a normative dimension any longer.

In February 1983, political scientist John Agresto (then assistant chairman of the Endowment and now president of St. John's College in Santa $\mathrm{Fe}$ ) was called upon by Chairman William J. Bennett to report to the National Council on the vexed question of a principled basis for "the funding of the social sciences." In researching the matter Agresto discovered that three major papers on the subject had been prepared by the Council soon after the establishment of the Endowment (1967-1968) in a concerted effort to improve on the congressional device of merely listing disciplines by way of defining who qualifies for support. None of these early efforts had met with acceptance.

Agresto acknowledged that for much of the life of the agency the de facto criterion for separating the social sciences from the humanities, one that had found its way into the guidelines of NEH programs, was quantification and empiricism: "if the study was predominantly quantitative or empirical it was ineligible. Such a dividing rule, however, seems increasingly to ignore the real difference between the two areas, to fuel the notion that the social sciences are empirical and the humanities merely impressionistic, and to overlook the work properly done in the humanities which has been somewhat quantitative." The rough rule of thumb that came of Agresto's ruminations leaned on the legislative language. Thus, he wrote,
"by the humanities we mean "the study of history, literature, philosophy,' etc. . . . [I]f we begin with a disciplinary approach, we can have as a rough and ready guide, the following criterion: Studies in the social sciences that are essentially historical or philosophical in nature are, for our purposes, sufficiently within the humanities [to qualify for consideration for support by NEH]" (Agresto, "Funding of Social Sciences").

Agresto continued: "There is no hard and fast dividing line between the humanities and the social sciences." And with a sly bow to Aristotle he concluded, "They are imprecise descriptions of phenomena not found in nature, and we shouldn't seek to impose greater clarity than imprecise matter itself allows" (Agresto, "Funding of Social Sciences"). There the question stands. Agresto's memorandum, too, was neither accepted nor rejected by the Council but merely received and, thus, has no official status as providing a criterion or definition.

\section{How well are political scientists funded?}

Imprecision about who qualifies and who does not has not daunted applicants, however. A general sense of the growth of NEH can be gained by reflecting that from its first two years with a staff of 30 people it has grown to 260; and from two grants awarded in those first two years and worth a total of $\$ 39,000$, the agency 
last year considered 8,037 applications, brought almost 1,000 panelists to Washington and consulted another 7,700 scholars by mail seeking advice on the quality and significance of these applications, and made some 2,300 grants worth $\$ 137,000,000$. "Over the twenty-five years of the Endowment's existence, 144,000 applications have been reviewed and 41,000 grants made, totaling $\$ 1.97$ billion" (Humanities, 7).

As mentioned at the outset, a substantial amount of federal money was spent on political science projects in the Reagan Era alone: 412 projects received $\$ 13,577,147$ from FY 1981 through FY 1989. A comparison made several years ago indicated that political scientists then received as much support from NEH as from NSF, if not more. Data on the pre-computerized earlier period and data showing the success rates specifically for political science applicants are not readily available. Moreover, the disparities in the size of grants and the fuzziness of classification of "political science grants" suggests that the available statistics be used with care. Nonetheless, the record remains impressive.

Some examples may be adduced. Thus, in FY 1981 the largest grant identified by NEH as a "political grant" was $\$ 300,000$ awarded to the Council on Foreign Relations for a regrant program in fellowships. The smallest award went to an individual who received $\$ 1,625$ for a project entitled "Historical Study of Trends in American Social Science:

1949-1964" and described as "To support a manuscript on the relationship between liberal social science and right-wing movements in the U.S." Several runners-up in the small grant category that year were in the $\$ 2,500$ class and addressed the subjects: (1) "the post-1909 writings of Mao Tse-tung" to be prepared for publication in " 16 annotated volumes"; (2) "development strategies in an oil-exporting nation: the case of Mexico"; and (3) "On the Outside Lookin' In: The Politics of Appalachia (introductory paperback text and trade book)." The grant to the Council on Foreign Relations constituted $21 \%$ of the funds awarded "political science" in FY 1981.

Support for political science peaked in the bicentennial years. The largest single year for awards to political science was FY 1986 when 73 applicants received $\$ 2,695,121$. Again some examples are instructive. The largest sums went to two successful applicants in General Programs for film projects that totaled $\$ 996,000$ or $37 \%$ of the total. These grants were to: Metropolitan Pittsburgh Public Broadcasting to support "Visions of the Constitution" in producing two 60-minute documentary programs as part of a nine-part series on the U.S. Constitution $(\$ 700,000)$; and, a Pennsylvania foundation to support "Visions of Social Order" in producing a 60-minute television documentary on the life and philosophy of Karl Marx as a pilot for a 13-part series on political philosophers $(\$ 296,000)$. The early supporters would have appreciated the contrasting normative perspectives reflected in these two awards. A further large grant that year was to APSA for publication and distribution of this Constitution: A Bicentennial Chronicle during 1987 and $1988(\$ 175,000)$. At the small end of the awards were ten $\$ 500$ grants for travel to collections to

\begin{tabular}{|c|c|c|}
\hline \multicolumn{3}{|c|}{$\begin{array}{l}\text { TABLE } 1 . \\
\text { Political Science Grants } \\
\text { Funded by NEH, } \\
\text { Fiscal Years 1981-1989 }\end{array}$} \\
\hline Fiscal Year & $\begin{array}{l}\text { Number of } \\
\text { Projects }\end{array}$ & $\begin{array}{l}\text { Dollars } \\
\text { Obligated }\end{array}$ \\
\hline 1981 & 39 & $\$ 1,419,906$ \\
\hline 1982 & 30 & 727,101 \\
\hline 1983 & 37 & $1,009,528$ \\
\hline 1984 & 55 & $1,747,610$ \\
\hline 1985 & 50 & $1,710,732$ \\
\hline 1986 & 73 & $2,695,121$ \\
\hline 1987 & 49 & $2,112,245$ \\
\hline 1988 & 47 & $1,247,465$ \\
\hline 1989 & 32 & 907,439 \\
\hline TOTALS & 412 & $\$ 13,577,147$ \\
\hline
\end{tabular}

research an array of subjects, including "Economic Policymaking in the Truman Administration," "The United States and the Polish Underground During World War II," and "A Political History of Inflation in 20th Century America."

Periodic soul-searching goes on within the NEH about the justifiability of spending large sums on films by comparison with the meager cost of supporting other program

\section{TABLE 2.}

Political Science Grants Funded by NEH, Fiscal Year 1986

Total Projects Funded:

Total Obligated Amount for FY 1986:

Summaries by Program:

\begin{tabular}{crrrr} 
Program & Project No. & Approved & Funded & Obligated \\
\hline ES & 2 & $135,868.00$ & $135,833.08$ & $135,868.00$ \\
FA & 12 & $330,000.00$ & $302,300.00$ & $304,400.00$ \\
FB & 3 & $70,178.00$ & $55,578.00$ & $55,578.00$ \\
FE & 10 & $5,000.00$ & $5,000.00$ & $5,000.00$ \\
FI & 18 & $35,600.00$ & $35,600.00$ & $35,600.00$ \\
FS & 5 & $337,743.00$ & $322,101.70$ & $329,181.00$ \\
FT & 10 & $30,000.00$ & $30,000.00$ & $30,000.00$ \\
FV & 6 & $335,645.00$ & $323,544.31$ & $335,645.00$ \\
GB & 5 & $565,811.00$ & $531,781.00$ & $467,849.00$ \\
GN & 2 & $996,000.00$ & $995,533.51$ & $996,000.00$ \\
\hline
\end{tabular}

Abbreviations Used:

ES Elementary \& Secondary Education

FA Fellowships for University Teachers

FB Fellowships for College Teachers and Independent Scholars

FE Fellowships for Travel to Collections

FI Fellowships for Younger Scholars

FS Fellowships/Summer Seminars for College Teachers

FT Fellowships/Summer Stipends

FV Fellowships/Summer Seminars for School Teachers

GB General Programs/Bicentennial Projects

GN General Programs/Media

Source: NEH. 
activities, as just illustrated. Into this debate is thrown other issues as well, such as the kind of balance to be maintained between public and general-appeal activities in comparison with purely academic and scholarly activities. The advocates of television may be said to have reached a turning point in the debate after The Adams Chronicles, a 13-part series covering the famous

\section{TABLE 3.}

\section{Political Science Grants Funded by NEH, Fiscal Year 1987}

Total Projects Funded:

Total Obligated Amount for FY 1987:

$\$ 2,112,245.00$

Summaries by Program:

\begin{tabular}{crrrr} 
Program & Project No. & Approved & \multicolumn{1}{c}{ Funded } & Obligated \\
\hline ES & 1 & $94,000.00$ & $90,906.00$ & $90,906.00$ \\
FA & 5 & $137,500.00$ & $129,850.00$ & $129,850.00$ \\
FB & 1 & $27,500.00$ & $27,500.00$ & $27,500.00$ \\
FE & 4 & $3,000.00$ & $3,000.00$ & $3,000.00$ \\
FI & 11 & $21,400.00$ & $21,400.00$ & $21,400.00$ \\
FS & 5 & $376,700.00$ & $373,510.08$ & $373,380.00$ \\
FT & 10 & $35,000.00$ & $35,000.00$ & $35,000.00$ \\
FV & 5 & $308,089.00$ & $308,089.00$ & $308,089.00$ \\
GB & 3 & $367,884.00$ & $367,884.00$ & $240,020.00$ \\
GM & 1 & $23,554.00$ & $19,419.00$ & $19,419.00$ \\
GN & 1 & $800,609.00$ & $800,609.00$ & $800,609.00$ \\
RL & 1 & $50,072.00$ & $50,072.00$ & $50,072.00$ \\
RX & 1 & $13,000.00$ & $9,369.52$ & $13,000.00$ \\
& 1 & & &
\end{tabular}

Abbreviations Used:

GM General Programs/Museums

RL Research Programs/Translations

RX Research Programs/Conferences

Source: NEH.

TABLE 4.

Political Science Grants Funded by NEH, Fiscal Year 1988
Total Projects Funded:

Total Obligated Amount for FY 1988:

Summaries by Program:

\begin{tabular}{ccrrr} 
Program & Project No. & Approved & Funded & Obligated \\
\hline ES & 1 & $323,492.00$ & $323,492.00$ & $153,419.00$ \\
FA & 3 & $67,815.00$ & $67,815.00$ & $67,815.00$ \\
FB & 8 & $210,768.00$ & $210,768.00$ & $210,768.00$ \\
FE & 8 & $6,000.00$ & $6,000.00$ & $6,000.00$ \\
FG & 2 & $54,242.00$ & $54,242.00$ & $54,242.00$ \\
FI & 8 & $16,800.00$ & $16,800.00$ & $16,800.00$ \\
FS & 3 & $265,558.00$ & $256,217.53$ & $186,339.00$ \\
FT & 7 & $24,500.00$ & $24,500.00$ & $24,500.00$ \\
FV & 2 & $144,592.00$ & $144,592.00$ & $144,592.00$ \\
GP & 2 & $180,990.00$ & $180,990.00$ & $180,990.00$ \\
RO & 2 & $222,000.00$ & $202,000.00$ & $187,000.00$ \\
RX & 1 & $20,000.00$ & $20,000.00$ & $15,000.00$
\end{tabular}

Abbreviations Used:

FG Fellowships/HBCU (Historically Black Colleges and Universities) of Graduate Fellowships GP General Programs/Public Humanities Projects

RO Research Programs/Collaborative Research

Source: NEH.
American family from 1750 to 1900 , received 27 nominations and won four Emmy awards in 1976 and 1977 programs have gained momentum in over the last decade. The case in point. The 1987 "Bicentennial Bookshelf Awards" provided $\$ 500$ and also won the George Peabody

\section{Is there a political science connection?}

Since the APSA was part of the original consortium of learned societies urging creation of the Endowment, and in advocating the reauthorization legislation for the agency after 20 years in 1985, it might be expected that APSA should have received some direct support from NEH. But this was surprisingly late in coming. By far the largest grants to the Association were awarded for the previously noticed project, viz., to publish and distribute this Constitution. Such grants total $\$ 586,684$ to date. These funds were part of the Endowment's emphasis upon the bicentennial and its increasing concern with the quality of humanities educationincluding citizenship training-especially at the precollegiate level.

The very first grant to APSA was awarded in 1974 when, with the late Herbert Storing as principal investigator, it received $\$ 11,440$ to support participation of scholars in two congresses on the bicentennial theme of "The American Polity 1776-1976." In the following year, APSA received $\$ 80,625$ to initiate a series of Perennial Issue Papers in Political Science, intended for use of faculty members who teach the concepts of political and ethical theory. In 1979 a further grant in the amount of $\$ 99,178$ was awarded APSA to fund a program entitled "Ethical Issues: Citizenship and Political Education" to be conducted by five political philosophy scholars as seminars for 100 college teachers so as to improve the classroom teaching of American politics. A grant of $\$ 100,747$ was awarded APSA in FY 1981 to develop a sourcebook for teaching about the U.S. Constitution at the eleventh and twelfth grade levels. The grand total of NEH money directly funding APSA projects 
during the Endowment's first 25 years comes to $\$ 903,198$.

Another aspect of political science involvement with $\mathrm{NEH}$ is the appointment of political scientists as members of the National Council on the Humanities, a presidential commission. Of the 117 persons to have served on the Council, at least 17 were or are political scientists. Two presidents of APSA have been members of the NEH Council-Robert E. Ward (Stanford) and Emmette S. Redford (Texas). The high tide of political science influence on the Council and within the agency came in 1984 when Council memberpolitical scientists included William B. Allen (Claremont), Walter Berns (Georgetown), George W. Carey (Georgetown), Samuel Dubois Cook (Dillard), Charles V. Hamilton (Columbia), James V. Schall (Georgetown), Harriet M. Zimmerman (unaffiliated), and the author-or eight of the 26 Council members, plus John Agresto (a Cornell Ph.D.), assistant chairman, were political scientists, all of them with primary professional interests in political philosophy and/or constitutional law. ${ }^{2}$

Whatever the full explanation of this concentration of political scientists in recent years on the National Council, a contributing factor was the coincidence of the bicentennial observances of both the Declaration of Independence and of the Constitution in this general period. Indeed, one of the significant pre-1980s awards made by NEH to a political scientist was to Robert A. Goldwin and the American Enterprise Institute in 1979, an award that eventually amounted to $\$ 192,000$ to fund a tenyear study of the Constitution. Cosponsored by the APSA, this resulted in Project ' 87.

In summary, without being able to demonstrate them here through a more detailed analysis, a variety of considerations lead to these general conclusions: political scientists have increasingly come to believe that applying to $\mathrm{NEH}$ for support is worth the time and effort; the number of applications are up from this clientele; the quality of applications is up; the agency has become more receptive to such projects (there are more members of NEH staff with a political science background and a significant fraction of the

\begin{tabular}{|c|c|c|c|c|}
\hline \multicolumn{4}{|c|}{$\begin{array}{l}\text { Total Projects Funded: } \\
\text { Total Obligated Amount for FY } 1989 .\end{array}$} & \multirow[t]{2}{*}{$\begin{array}{r}32 \\
\$ 907,439.00\end{array}$} \\
\hline \multicolumn{4}{|c|}{ Summaries by Program: } & \\
\hline Program & Project No. & Approved & Funded & Obligated \\
\hline FA & 2 & $55,000.00$ & $55,000.00$ & $55,000.00$ \\
\hline FB & 1 & $27,500.00$ & $27,500.00$ & $27,500.00$ \\
\hline FE & 7 & $5,250.00$ & $5,250.00$ & $5,250.00$ \\
\hline FI & 2 & $4,400.00$ & $4,400.00$ & $4,400.00$ \\
\hline FS & 3 & $261,934.00$ & $261,934.00$ & $172,847.00$ \\
\hline FT & 6 & $21,000.00$ & $21,000.00$ & $21,000.00$ \\
\hline FV & 4 & $227,182.00$ & $227,117.00$ & $227,117.00$ \\
\hline GL & 1 & $269,325.00$ & 269.325 .00 & 269.325 .00 \\
\hline GN & 2 & $1,640,609.00$ & $840,609.00$ & $40,000.00$ \\
\hline GP & 1 & $67,000.00$ & $67,000.00$ & $40,000.00$ \\
\hline RO & 1 & $135,000.00$ & $115,000.00$ & $15,000.00$ \\
\hline RX & 2 & $45,000.00$ & $45,000.00$ & $30,000.00$ \\
\hline \multicolumn{5}{|c|}{ Abbreviations used: } \\
\hline \multicolumn{5}{|c|}{ GL General Programs/Libraries and Archives } \\
\hline \multicolumn{5}{|c|}{ Source: NEH. } \\
\hline
\end{tabular}

agency's governing board, the National Council, are themselves political scientists who value good political science-related proposals), and the money invested in political science projects is on the increasewith the noted bulge around the bicentennial.

Lastly, however, the leadership of the Endowment in the past decade has contributed to the political aura of the agency and has made it eyecatching for political scientists.

Exactly how this fits is hard to determine with any precision. But the overtly activist role of $\mathrm{NEH}$ and its leadership has both attracted political scientists and probably also made the Endowment itself more receptive to proposals from them. First, Chairman William J. Bennett and then (since 1986) Chairman Lynne V. Cheney, in quite different ways, have focused national attention on the Endowment-not by partisan political activism! - but by striking out with missionary zeal to reform American education at all levels and to revive the general public's devotion to the enduring cultural legacy of our civilization. The NEH chairmanship has become a bully pulpit from which to inveigh, cajole, and agitate in a continuous national campaign to stamp out ignorance and rally support for the humanities. In a resonant national forum, two forceful chairmen have persistently linked histori- cal conservation and philosophical literacy, on one side, with personal liberty and free government on the other.

This is a profoundly political theme. It has been pursued in many lesser ways but also through major initiatives from Bennett's report entitled To Reclaim a Legacy (1984) to Cheney's Humanities in America (1988) and last year's 50 Hours: $A$ Core Curriculum for College Students. The self-generated mission of NEH seems to be to save the cultural heritage of the nation and civilization by all available means. To do this requires the rehabilitation of education in the humanities. Given the evangelical flavor of American politics homestyle, this is a mode of personalized crusading to which many citizens, including political scientists, respond.

By making a formidable case for its proposals, $\mathrm{NEH}$ has generated a place in the public eye incommensurate with its tiny staff and budget. It has become something of the conscience of the nation about the authors we haven't read but should, the rivers we can't find on the map, and the presidents whose times and actions are lost in the vast ignorance of forgottenness. Bill Bennett and Lynne Cheney have, by turn, and quite remarkably, so dramatized the issues as to transform their little agency into the gadfly of that great 
thoroughbred called America.

\section{Conclusion}

It is easy to see that the intensification of scholarly as well as general public concern with things political and with relocating the benchmarks of American political culturebrought on by many factors including the Vietnam War, the constitutional crisis called Watergate, multiple bicentennials of our nationhood, and by plausible appeals to patriotism as a major theme of the politics of the 1980s-has served to place NEH's and workaday political scientists' concerns in unexpected proximity. A historically and philosophically informed science of human affairs is being demanded by the times. This among other things muted and undermined the credibility of some of the heady claims earlier made on behalf of behavioral social science. That persuasion now tends to find its place as one strand among others in the many splendored thing called American political science. Dimensions of experience identified with religion, philosophy, literature, and history were willy nilly rediscovered to be essential aspects of political understanding and of reliable scientific knowledge about man; and the profound achievements by outstanding contemporary scholars in the field of political philosophy abetted this rediscovery. ${ }^{3}$ The National Endowment for the Humanities offered wonderful opportunities for scholars who imaginatively wished to enrich their political studies from the perspectives of these several modes-and it still does. The money is there. And in the logic of the ancient profession, what could be more natural?

With the dawn of a kind of American Renaissance breaking in the collapse of communist tyranny abroad because of a massive affirmation of the centrality of liberty to human existence, one can surmise that conditions will remain favorable for the prospering of this happy marriage between one small federal agency devoted to the humanities and American political scientists. The complexion of the discipline is changing, just as the world itself is changing. Political questions deeply moored in the tangles of historical diversity and cultural idiosyncracy are swirling to the surface of contemporary existence as urgent matters demanding comprehension and as pragmatic problems to be resolved. We can thus end with a prediction: the present trend toward greater involvement of political scientists with the disciplines of the humanities must inevitably continue and can be expected to accelerate in the decades ahead. For us to do otherwise would be to doom our science to obtuse irrelevance in a changing world.

Besides, we still have one more bicentennial to observe.

\section{Notes}

1. For detailed information on the operation, activities, and organization of $\mathrm{NEH}$ consult National Endowment for the Humanities: 24th Annual Report 1989 (Washington, 1989); the current composition of the National
Council on the Humanities is given ibid., 183. 2. It may be noted that William B. Allen began his term on July 2, 1984, while Charles V. Hamilton ended his service on the National Council on April 26, 1984; hence only seven political scientists served simultaneously on the Council.

3. For an early sketch of this development see Ellis Sandoz, "The Philosophical Science of Politics Beyond Behavioralism," in George J. Graham, Jr., and George W. Carey, eds., The Post-Behavioral Era: Perspectives on Political Science (New York, 1972), 285-305.

\section{References}

Agresto, John. Memorandum to William Bennett, "The Funding of the Social Sciences."

American Council of Learned Societies. 1964. "Statement of the American Political Science Association," Report of the Commission on the Humanities. Washington, DC.

Humanities 11 (1), 7. " $\mathrm{NEH}$ at 25: A Retrospective.

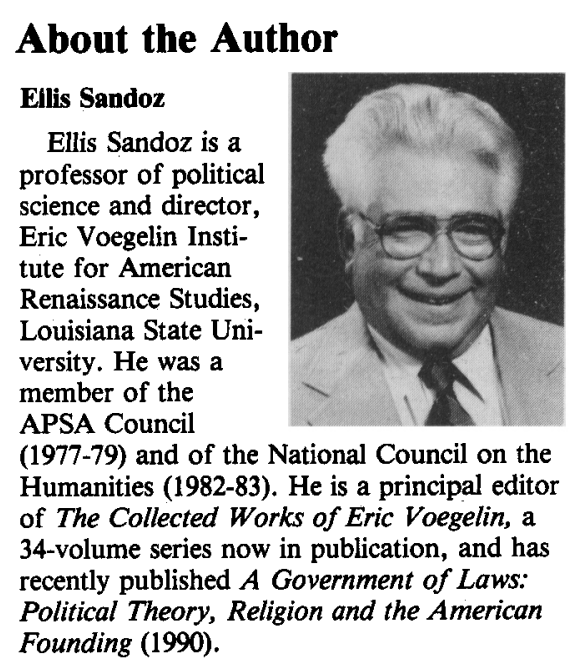

